\title{
THE ACTIVITY OF HETEROTROPHIC BACTERIA ON DOM - METAL COMPLEXES AFFECTS COPPER SPECIATION AND BIOAVAILABILITY IN AQUATIC ECOSYSTEM
}

\author{
NOGUEIRA, P.F.M.'; NOGUEIRA, M.M. ${ }^{2}$; MELÃO, M.G.G. ${ }^{3}$; \\ LOMBARDI, A.T. ${ }^{4}$ \\ 1 Universidade de São Paulo, Instituto de Física de São Carlos, Grupo de Nanomedicina e Nanotoxi- \\ cologia. \\ 2 Universidade de São Paulo, Escola de Engenharia de São Carlos, Núcleo de Estudos de Ecossiste- \\ mas Aquáticos. \\ 3 Universidade Federal de São Carlos, Dept. Hidrobiologia. \\ 4 Universidade Federal de São Carlos, Dept. Botânica. \\ *Corresponding author: pmayrink1@yahoo.com.br
}

\begin{abstract}
Nogueira, P.F.M.; Nogueira, M.M.; Melão, M.G.G.; Lombardi, A.T.(2014). Heterotrophic bacteria affect DOM-Copper dynamics. Braz. J. Aquat. Sci. Technol. 19(1):47-53. eISSN 1983-9057. DOI: 10.14210/bjast.v19n1.p47-53 The increasing eutrophication and contamination of aquatic ecosystems motivates the study of interactions between natural dissolved organic matter (DOM), metals and the biota. Metals are mainly released into the environment by industrial processes, whereas organic materials through municipal sewage sludge. The association of these two processes and its effect on the environment poses unknown risks to aquatic communities. This investigation focused on copper speciation in the presence of aquatic heterotrophic bacteria and natural dissolved organic materials and demonstrated a relevant environmental consequence of heterotrophic bacteria related to copper speciation in aquatic systems. The experiments consisted of bacteria cultures to which natural dissolved organic materials and copper were added. Copper dynamics during bacteria growth was evaluated through the determination of free $\mathrm{Cu} 2+$ ions, total dissolved copper, copper internalized and adsorbed onto bacteria surface during incubation. The results showed a reduction of organic carbon and an increase of free Cu2+ions in culture media. Significant ecological consequences are foreseen from the present results, since from less bioavailable forms of copper, bacteria released more toxic copper species into the environment.
\end{abstract}

Key words: copper speciation; toxicity; bacteria; dissolved organic matter; metal complex.

\section{INTRODUCTION}

The speciation of trace metals in natural waters is widely recognised as a key to understanding the ecotoxicological impacts. In freshwater ecosystems, the toxicity is strongly dependent on metals' speciation, where the key species is the free metal ion $(\mathrm{M}+)$, which is usually presumed to be in equilibrium with various dissolved or particulate ligands and with the epithelial or cell surfaces of aquatic organisms (Mueller, et al. 2012). A metal may follow several different pathways, like simple ionic interactions, particle association and precipitation, sediment deposit, chemical and biological oxidations, ligand complexation, and adsorption/ absortion by microorganisms in food webs (Sigg and Behra, 2005). So, in aquatic ecosystems trace metals may interact with organisms (Batley et al., 2004) and a variety of molecules that may include inorganic $\left(\mathrm{HCO}^{3-}\right.$, $\mathrm{CO}_{3}^{2-}, \mathrm{SO}_{4}^{2-}, \mathrm{HS}^{-}, \mathrm{Cl}^{-}$) and organic ligands (humic and fulvic acids, biological molecules, colloidal particles). The microbiota can affect the fate of many contaminants by contributing to their removal through uptake, degradation, or transformation (Ford and Mitchell, 1990). However, the introduction of metals in the en- vironment can produce considerable modifications of the microbial communities and their activities (Hassen et al., 1998).

The bioavailability and toxicity of trace metals to microorganisms are related to their ability to cross biological surfaces, which is influenced by the physicochemistry of the medium, size and nature of microorganisms, and most often predicted by the concentration of internalized metal (Worms et al. 2006). The modes of interaction between metal speciation and microorganisms are dominates by the presence and activity of microorganisms in natural aquatic ecosystems and can be having diversity forms: accumulation and efflux (Worms et al., 2006); ligand excretion (Nogueira et al., 2009; 2012) and adsorption onto cell wall (Maurice et al., 2004). The importance of natural DOM in the environment has been recognized due to its metal complex capacity (Reuter and Perdue, 1977). Thus, as supported by literature data, DOM-complexed metal is usually less to toxic microorganisms than free metal ions (Nogueira et al., 2005; 2009; 2012). The DOM also as energy source for heterotrophic bacteria assemblage (RomeraCastillo et al., 2011), and these organisms represent important components in aquatic systems, responsible 
for the regeneration of nutrients and transfer of carbon and energy (Kujawinski, 2011; Jiao et al., 2010).

Among trace metals, copper is an essential metal for microorganisms survival because its redox properties. It can be converted into oxidized $\left(\mathrm{Cu}^{2+}\right)$ and reduced $\left(\mathrm{Cu}^{1+}\right)$ states as catalytic cofactor in enzymatic reactions. Some copper dependent enzymes are $\mathrm{Cu} / \mathrm{Zn}$ superoxide dismutase (antioxidant defense), cytochrome c oxidase (mitochondrial respiration), lysyl oxidase (development of connective tissue), and trypsinase (melanin biosynthesis) (Shim et al., 2003) may be mentioned. Nevertheless, toxic effects are observed when copper concentrations exceed those needed for the healthy growth of the organisms. It has been shown that inside the cell, copper ions can accumulate and react to generate hydroxyl radicals that damage proteins, lipids and nucleic acids (Silver \& Phung, 2005). Consequentely, cellular healthy functioning is dependent on copper regulation by the organism, such as its transport, distribution and storage.

The aims of the present research were to evaluate the effects of activity of a bacteria community on natural DOM-copper complex and metal dynamic under laboratory controlled conditions. Information regarding the interactions of metals with aquatic biota and natural DOM are thus of great ecological interest and may give insights regarding metal transport and transformations in aquatic ecosystems. However, few investigations address copper speciation as it may be affected by microorganisms activity in the presence of natural DOM.

\section{Experimental design}

\section{METHODOLOGY}

Natural heterotrophic bacteria were exposed to 2 different treatments with 3 experimental replicates each: treatment with dissolved organic matter only (DOM), and treatment with copper and dissolved organic matter $(\mathrm{DOM}+\mathrm{Cu})$. At distinct incubation times $(0,0.5,2,4,6,12,24$ and 48 hours), heterotrophic bacteria density and DOM concentration was observed in DOM and DOM+Cu treatments, while copper dynamic (adsorbed, internalized, total and free copper) was evaluated in the $\mathrm{DOM}+\mathrm{Cu}$ treatment.

For each treatment, a fraction of natural bacteria population was obtained by filtering $700 \mathrm{~mL}$ of freshwater samples of tropical reservoir through $1.2 \mu \mathrm{m}$ glass fiber filter (GF/C, Whatman) to remove bacterivores, and than filtered on a acetate membrane filter with $0.2 \mu \mathrm{m}$ pore size (Sartorius). The retained bacteria on acetate membrane were used as inoculums in polycarbonate Erlenmeyer flasks filled with $700 \mathrm{~mL}$ of the autoclaved $\left(120^{\circ} \mathrm{C}, 30 \mathrm{~min}\right)$ reconstituted freshwater (APHA, 1995) with DOM or DOM+Cu.
After inoculation, the experimental flasks were incubated in the dark on a shaker at $60 \mathrm{rpm}$ (Nova Ética, Brazil), temperature of $25^{\circ} \mathrm{C} \pm 2$ (Tranvik \& Sieburth, 1989) and a pH 6.8. Bacteria density was quantified at time $0 ; 0.5 ; 2 ; 4 ; 6 ; 12 ; 24$ and $48 \mathrm{~h}$, through light absorption (540 nm, Shimadzu spectrophotometer, Japan) according to Lores et al. (1999).

In the different incubation times, samples (50 $\mathrm{mL}$ ) were taken and filtered through $0.2 \mu \mathrm{m}$ pore size acetate membrane filters (Sartorius). These filters were further used for the determination of adsorbed and internalized copper, and the filtrate was used for dissolved copper determinations (total and free copper ions) and total organic carbon (TOC-5000 Analyzer, Shimadzu, Japan).

To report internalized and adsorbed copper per unit bacteria cells, the organisms were preserved with formalin $4 \%$, stained with $0.125 \mathrm{mg}^{\mathrm{mL}} \mathrm{L}^{-1}$ of DAPI (4',6-diamidino-2-phenylindole) and counted on 0.2 $\mu \mathrm{m}$ pore size black filters (Ispore, Millipore) under an epifluorescence microscope (Porter \& Feig, 1980).

Only polycarbonate and Teflon $\AA$ laboratory materials were used throughout. As routine, these were washed with $1.0 \mathrm{~mol} \mathrm{~L}^{-1} \mathrm{HCl}$ (7 days) and rinsed with glass distilled water prior to use. Acetate filters (0.2 $\mu \mathrm{m}$ - Sartorius) were washed with $1.0 \mathrm{~mol} \mathrm{~L}^{-1} \mathrm{HCl}(12$ hours) and rinsed with glass distilled.

Suwannee River Natural Organic Matter (SRNOM) commercialized by the International Humic Substances Society was used as natural dissolved organic material (DOM) for the experiments. It was added in a concentration of $10.0 \mathrm{mg} . \mathrm{L}^{-1}$, quantified as $7.0 \mathrm{mg} \cdot \mathrm{L}^{-1}$ total organic carbon using an organic carbon analyzer (TOC-5000 Analyzer, Shimadzu, Japan).

Copper was furnished as $\mathrm{CuCl} 2$ (Titrisol, Merck) in a total initial dissolved concentration of $1.8 \times 10^{-6}$ mol. $L^{-1}$. Copper was quantified as particulate, total dissolved and free $\mathrm{Cu}^{2+}$ ions.

\section{DOM copper complex capacity}

The DOM complexation capacity for copper binding was previously determined to adjust the concentration of total copper to be added in the beginning of the experiments, so few copper would remain as free $\mathrm{Cu}^{2+}$ species.

The copper complexing properties ( $\mathrm{K}^{\prime}$ and $\mathrm{CL}$ ) were previously determined through copper titrations. Titrations were performed by incrementally adding copper from $8 \times 10^{-7}$ to $4.4 \times 10^{-5} \mathrm{~mol}^{-\mathrm{L}^{-1}}$ and detected as free $\mathrm{Cu}^{2+}$ ions using ion selective electrode (Analion, Ribeirão Preto, Brazil). Three replicate titrations were performed on $10 \mathrm{mg} \cdot \mathrm{L}^{-1}$ aqueous solution of the DOM previously filtered through acid cleaned $\left(\mathrm{HNO}_{3} 1.0 \mathrm{~mol}\right.$ $\left.\mathrm{L}^{-1}\right) 0.2 \mu \mathrm{m}$ membrane filter. Titrations were buffered with PIPES (piperazine-N,N'-bis[2-ethanesulfonic 
acid], Sigma-Aldrich) at $\mathrm{pH} 6.8$ and a final concentration of $7 \times 10^{-3} \mathrm{~mol}^{-1}$. Ionic strength was kept at $10^{-1} \mathrm{~mol} \mathrm{~L}^{-1}$ using ultrapure $\mathrm{NaNO}_{3}$ (Fluka Chemie, MicroSelect). Blank copper titrations were performed on reconstituted freshwater without $\mathrm{DOM}$. Titration data were converted from millivolts to $\mathrm{pCu}=-\log \left[\mathrm{Cu}^{2+}\right]$ by means of the Nernst equation, in which the electrode slope $(29-30 \mathrm{mV})$ was obtained from daily performed electrode calibration curves. Scatchard Plots were used to obtain $\mathrm{K}^{\prime}$ and $\mathrm{CL}\left(\mu \mathrm{mol} \mathrm{L}^{-1}\right)$ values; mean $\mathrm{CL}$ value have delineated the total copper concentration to be added at the beginning of the experiments.

\section{Copper determinations}

Filtrate samples $(10 \mathrm{~mL})$ were acidified using ultra pure HNO3 (Fluka Chimie, Switzerland) to a final concentration of $2.0 \mathrm{~mol} \mathrm{~L}^{-1}$ and followed to Atomic Absorption Spectroscopy (AAS-GF) analysis using a Varian AA220 instrument (Mulgrave, Australia) equipped with graphite furnace (Eletrochemical Trace Analyser, MD394) for total dissolved copper determination.

Free $\mathrm{Cu}^{2+}$ ions were determined immediately after sampling in $40 \mathrm{~mL}$ aliquots of the filtrate using ion selective electrode (ORION, USA) under controlled experimental conditions. Potential readings were obtained using a Digimed DMPH-2 $\mathrm{pH}$ meter with 0.01 $\mathrm{mV}$ resolution at constant temperature $\left(25^{\circ} \mathrm{C} \pm 1\right)$ together with a glass double-junction reference electrode $\mathrm{Ag} / \mathrm{AgCl}$ (ANALION, Brazil). $\mathrm{NaNO}_{3}$ was used as internal bridge at a concentration of $1.0 \mathrm{~mol} \mathrm{~L}^{-1}$. Sample ionic strength was adjusted to $0.1 \mathrm{~mol} \mathrm{~L}^{-1}$ using high purity NaNO3 (MicroSelect, Fluka, Switzerland). Copper measurements were reproducible to $\pm 4 \%$. Metal-ion buffers were used for electrode calibration and prepared as described in Lombardi et al. (2007).
They extended the lower limit of free copper ions determination to $5 \times 10-12$ mol.L $^{-1}$. Daily Cu-ISE calibration curves were performed.

For particulate copper determination (adsorbed onto bacteria cell surface and internalized), an aliquot of bacteria culture $(50 \mathrm{~mL})$ filtered through $0.2 \mu \mathrm{m}$ pore size acetate membrane filter (Sartorius) was rinsed with $5 \mathrm{~mL}$ of $2 \times 10-2 \mathrm{~mol} \mathrm{~L}^{-1}$ EDTA $(\mathrm{C} 10 \mathrm{H} 16 \mathrm{~N} 2 \mathrm{O} 8)$ at $\mathrm{pH} 7.0$ for $30 \mathrm{~s}$ according to the procedure described in Mirimanoff \& Wilkinson (2000). The $5 \mathrm{~mL}$ EDTA solution was completed to $50 \mathrm{~mL}$ with glass distilled water and filtered $(0.2 \mu \mathrm{m}$ - Sartorius). The filtrate was acidified (HNO3 - $2.0 \mathrm{~mol} \mathrm{~L}^{-1}$ ) for adsorbed copper determination through AAS-GF and the filter was dried overnight $(60$ ${ }^{\circ} \mathrm{C}$ ), acid digestion (HNO3) according to APHA (1995) and followed to internalized copper determination through AAS-GF.

\section{Statistical analysis}

Statistical analyses were performed using the InStat $₫$ software. ANOVA and Tukey-Kramer post test were used to contrast the concentration of each copper species (free, adsorbed and internalized) among experimental times $(0,0.5,2,4,6,12,24$ and 48 hours $)$.

\section{RESULTS \\ DOM copper complex capacity \\ Scatchard Plot Analysis of SR-NOM titration data showed that two copper complexing ligands were present (Figure 1). Stronger (K'1) ligands with log conditional stability constant of 7.47 present at $3.7 \times 10^{-6} \mathrm{~mol} \mathrm{~L}^{-1}$ concentration, and weaker ligands with log conditional stability constant of 5.00 at a concentra- tion of $7.6 \times 10^{-6} \mathrm{~mol} \mathrm{~L}^{-1}$ were detected in the SR-NOM.}

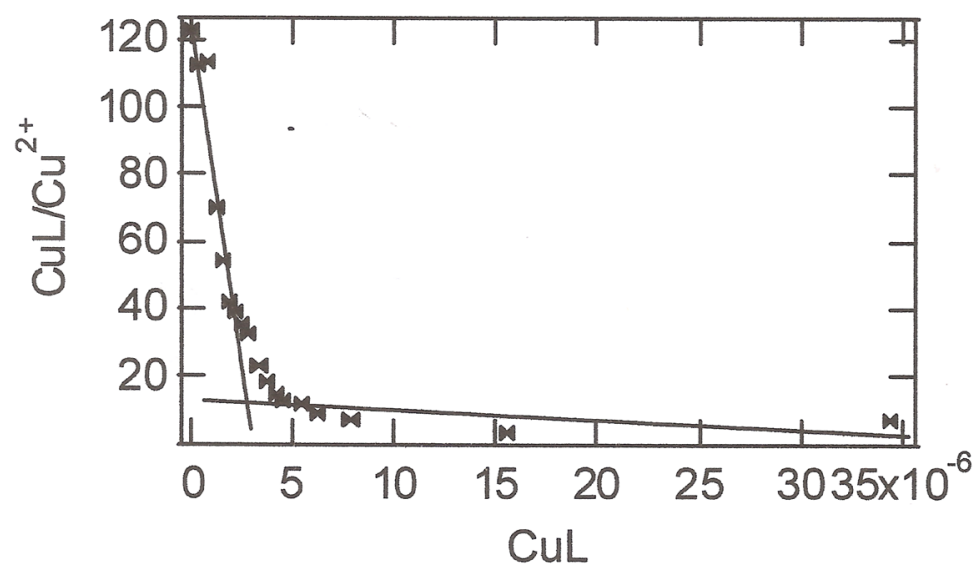

Figure 1 - Ion selective electrode calibration curve using metal buffers. Free copper concentration plotted as function of potential readings. 


\section{Bacteria density on dissolved organic carbon}

Heterotrophic bacteria density and DOC as function of experimental time is reported in figure 2 . It shows that the highest population density was quantified at 24 and $48 \mathrm{~h}$ of incubation and copper affected the growth (DOM+Cu treatment). At this experimental time (24 and 48h), total dissolved organic carbon was $4 \mathrm{mg} \mathrm{C} \mathrm{L}^{-1}$, value that corresponded to $57 \%$ of total furnished carbon as natural DOM (figure 2).

\section{Copper dynamic in the experiments}

Figure 3 reports free $\mathrm{Cu}^{2+}$ ions, adsorbed and internalized copper concentrations in the experiments as function of time after bacteria inoculation. It shows an increase of free $\mathrm{Cu}^{2+}$ ions in $2 \mathrm{~h}$ bacteria incubation ( $p<0.001$, ANOVA), which decreased afterwards $(p<0.001, A N O V A)$. While free $\mathrm{Cu}^{2+}$ ions concentration was kept low (10-9 mol.L-1), a gradational increase of adsorbed copper was observed $(4-12 h)(p<0.001$, ANOVA). In 24h of incubation the adsorbed copper decreased and can be observed an increase of internalized copper ( $p<0.001$, ANOVA). In $48 \mathrm{~h}$ incubation all copper species appear low probably because of increased bacteria cell number. Total dissolved copper concentration decreased and remained nearly constant $\left(0.91 \times 10-6+0.05 \times 10^{-6} \mathrm{~mol} \mathrm{~L}^{-1}\right)$ during the whole incubation period.

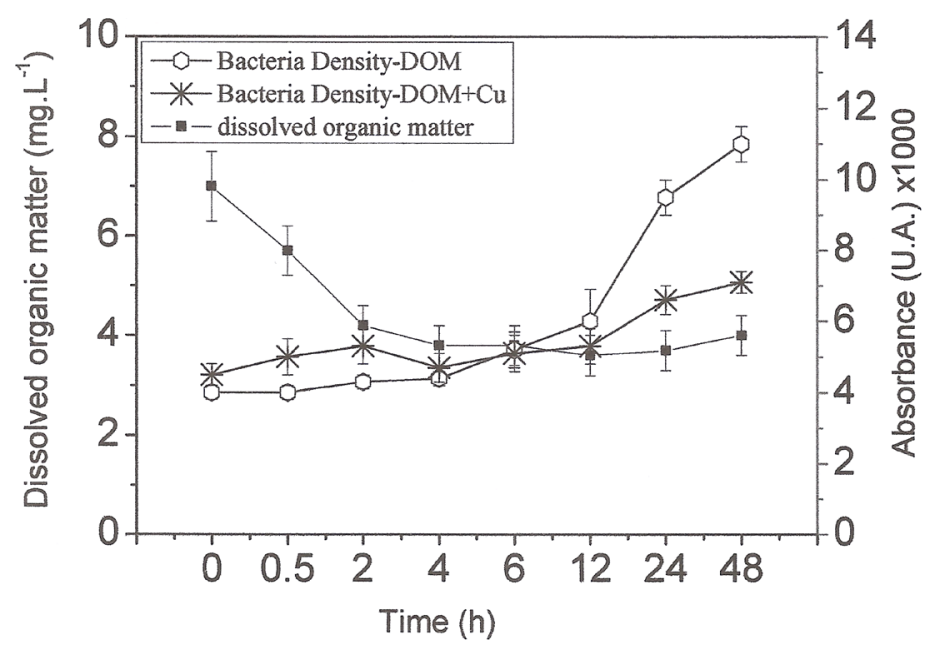

Figure 2 - Bacteria density curve (absorbance at $540 \mathrm{~nm}$ ) and dissolved organic carbon concentration (mg.L-1) as function of time. Values are mean $+S D$ of three experimental replicates.

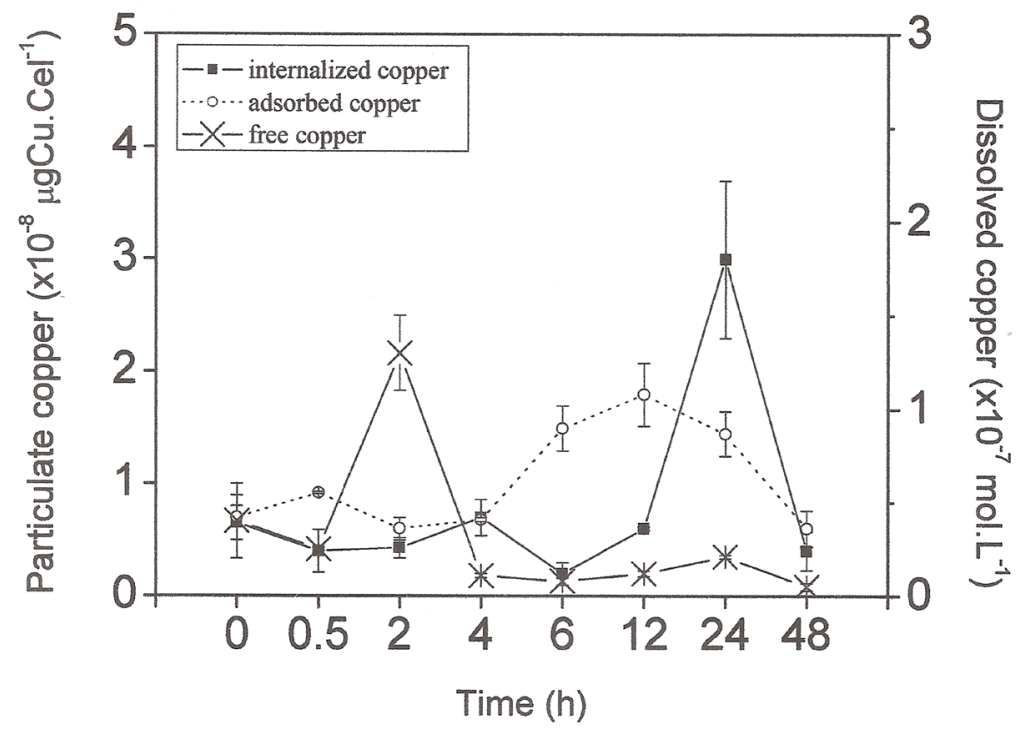

Figure 3 - Particulate copper (adsorbed and internalized) and free copper ions as function of experimental time. Values are mean $+\mathrm{SD}$ of three experimental replicates. 


\section{DISCUSSION}

\section{DOM-copper complexation capacity}

The results of complexation showed that the SRNOM have a stronger complexation capacity $\left(3.7 \times 10^{-6}\right.$ mol.L-1) of copper. According to Mueller et al. (2012), natural organic matter (NOM) plays a predominant role in complexing metals in aquatic environment. The capacity of complexation of dissolved SR-NOM in this work is higher than copper concentration $\left(1.7 \times 10^{-6}\right.$ mol. $\left.\mathrm{L}^{-1}\right)$ used, demonstrating that all of most copper inoculated was complexed, few remaining as the highly bioavailable free $\mathrm{Cu}^{2+}$ ion species.

\section{Bacteria density on dissolved organic carbon}

Dissolved organic carbon (DOC) reduction observed in cultures could either be due to use as energy source by the bacteria (Docherty et al., 2006; Romera-Castillo et al., 2011) and/or its adsorption onto bacteria cell surface (Esparza-Soto \& Westerhoff, 2003; Maurice et al., 2004).

Literature data (Moran and Hodson, 1990; Ellis et al., 2000) indicate that refractory materials, like humic substances, are of difficult degradation by microorganisms. Moran and Hodson (1990) showed that the labile DOM fraction from a lake supported a fourfold higher secondary production than humic substances from the same environment. Ellis et al. (2000) showed that microbial growth rate in refractory humic acid treatments was lower than in more labile amino acid and carbohydrate treatments.

Nevertheless, in this study, the increased of bacteria density, a reduction of DOM concentration and an increase of free $\mathrm{Cu}^{2+}$ ions detected in $2 \mathrm{~h}$ of incubation is indicative that the DOM was used as energy source by bacteria assemblage. These results are in agreement with literature data, where Docherty et al. (2006) reports on the degradation of refractory organic matter by bacteria and obtained a significant positive correlation between the concentration of humic materials and microbial assemblage activity and composition. The authors followed the degradation of natural DOM of several molecular weights and concluded that microbial assemblage growth could be supported by a variety of different DOM types, raveling metabolic versatility in relation to its adjustment and adaptations to new carbon sources in the environment. Also, the authors showed that high molecular weight DOM, normally considered as refractory organic materials were used by the bacteria.

\section{Copper dynamic in the experiments}

The role of chemical speciation on metal bioavalability is often successful in predicting a reduction in trace metal effects due to complexation (eg. Organic li- gands) or competition (eg. $\mathrm{H}^{+}, \mathrm{Ca}^{2+}$ ), both processes result in a decreased interaction of metal with uptake sites on organisms surface (Trenfield et al., 2011; Wang et al., 2010). Metal complexes can be altered by activity of bacteria, what have ecological consequences since they may modify metal speciation in the environment not only through the excretion of DOM, but also by DOM modification (Hur et al., 2011). So, considering that organism-metal interaction depends on metal speciation, the increase of free $\mathrm{Cu}^{2+}$ ions as result of bacteria activity may affect such interactions and consequently metal bioavailability.

The results demonstrated an increase of free $\mathrm{Cu}^{2+}$ ions $(2 \mathrm{~h})$ followed by an increase of adsorbed $(12 \mathrm{~h})$ and then internalized (24h) copper, and that bacteria density in DOM-Cu treatment was lower than control. So, the heterotrophic bacteria activity upon DOM makes available toxic specie of copper (free $\mathrm{Cu}^{2+}$ ions in $2 \mathrm{~h}$ of incubation).

These results indicate that copper internalization flux across the plasma membrane and toxicity is a function of the free metal ion concentration in the bulk solution. The effect of natural organic ligands on metal speciation and its availability and toxicity to bacteria has been discussed in literature (Keung et al., 2008; Kungolos et al., 2006; Smiejan et al., 2003). Kungolos et al. (2006) demonstrated that copper bioaccumulation in the photobacterium Vibrio fischeri decreased with the addition of humic acid, and that free $\mathrm{Cu}^{2+}$ ions were responsible for the toxic effects observed. Smiejan et al. (2003) found that Cd uptake by the freshwater bacterium Rhodospirillum rubrum was a function of free $\mathrm{Cd}^{2+}$ ion concentration. Keung et al. (2008) showed that $\mathrm{Cd}$ and $\mathrm{Zn}$ uptake by the bacteria Bacillus firmus correlated best with the free metal concentration than to hidrophilic metal-complexes.

These results is according to the free ion activity model (FIAM) that explain the relation between the free metal ion concentration in the bulk solution and the biological responses in organisms (Morel \& Hering 1983). The FIAM assumes that the plasma membrane is the primary site for metal uptake, consequently metal internalization flux across the plasma membrane is a function of the free metal ion concentration in the solution. Finally, van Leeuwen et al. (2005) proposed that organic complexed metal ions, like a DOM-Cu complex have lower diffusion coefficient across microorganisms cell wall, thus resulting in lower internalization. So, the free ion concentration is show to correlate best to bioavailability and toxicity.

\section{CONCLUSION}

The complexes of metals are the predominant form that was finding in the aquatic ecosystems (> 90 
$\%$, so this is ecological important the determination of quantitative contribution of these complexes to the metal take up processes to the organisms (Worms, 2006). From the present results, we conclude that bacteria activity upon DOM-metal complex have modified the speciation of copper in its surrounding environment, turning low bioavailability copper (complexed with DOM) onto the highly bioavailable free $\mathrm{Cu}^{2+}$ ions species.

\section{REFERENCES}

Alderkamp, A.C.; Buma, A.G.J.; van Rijssel, M. 2007. The carbohydrates of phaeocystis and their degradation in the microbial food web. Biogeochemistry 83: 99-118.

APHA (1995) Standard Methods for the Examination of Water and Waste Water, 2nd edn, DC, Washingnton.

Batley, G.E.; Apte, S.C.; Stauber, J. L. 2004. Speciation and bioavailability of trace metals in water: progress since 1982. Aust. J. Chem. 57: 903-919.

Docherty, K.M.; Young, K.C.; Maurice, P.A.; Bridgham, S.D. 2006. Dissolved organic matter concentration and quality influences upon structure and function of freshwater microbial communities. Microbial Ecol. 52:378-388.

Ellis, B.D.; Butterfield, P.; Jones, W.L.; Mcfeters, G.A.; Camper, A.K. 2000. Effects of carbon source, carbon concentration, and chlorination on growth related parameters of heterotrophic biofilm bacteria. Microbial Ecol. 38:330-347.

Esparza-Soto, M.; Westerhoff, P. 2003. Biosorption of humic and fulvic acids to live activates sludge biomass. Water Res. 37:2301-2310.

Ford, T.E., Mitchel, R. 1990. Microbial transport of toxic metals. In: Mitchel, R. (ed) Environmental Microbiology. Willey-Liss, Nova York. pp 91-238.

Hassan, S. H. A.;Kim, S. J.; Jung, A.Y; Joo J. H.; Oh, S. E.; Yang, J. E. 2009. Biosorptive capacity of Cd (II) and $\mathrm{Cu}$ (II) by lyophilized cells of Pseudomonas stutzeri. J. Gen. Appl.Microbiol. 55: 27-34.

Hur, J.; Lee, B.M.; Shin, H.S. 2011. Microbial degradation of dissolved organic matter (DOM) and its influence on phenanthrene-DOM interactions. Chemosphere 85: 1360-1367.

Jiao, N.Z.; Herndl, G.J.; Hansell, D.A.; Benner, R.; Kattner, G., et al. 2010. Microbial production of recalcitrant dissolved organic matter: long-term carbon storage in the global ocean. Nat. Rev. Microbiol. 8:593-599.

Keung, C.F.; Guo, F.; Qian, P.; Wang, W.X. 2008. Influences of metal-ligand complexes on the cadmium and zinc bioknetics in the marine bacterium Bacillus firmus. Environ. Toxicol. Chem. 27:131-137.
Kujawinsk, E.B. 2011. The impact of microbial metabolism on marine dissolved organic matter. Annu. Rev. Mar. Sci. 3:567-599.

Kungolos, A.; Samaras, P.; Tsiridis V.; Petala M.; Sakellaropoulos G. 2006. Bioavailability and toxicity of heavy metals in the presence of natural organic matter. J. Environ. Sci. Health, 41:1509-1517.

Lombardi, A.T.; Hidalgo, TR.; Vieira, A.A.H.; Sartori, A.L. 2007. Toxicity of ionic copper to the freshwater microalgae Scenedesmus acuminatus (Chlorophyceae, Chlorococcales). Phycologia 46:74- 78.

Lores, E.M.; Snyder, R.A.; Pennock, J.R. 1999. The effect of humic acid on uptake-adsorption of copper by a marine bacterium and two marine ciliates. Chemosphere 28: 293-310.

Maurice, P.A.; Manecki, M.; Fein, J.B.; Schaefer, J. 2004. Fractionation of an aquatic fulvic acid upon adsorption to the bacterium Bacillus subtilis. Geomicrobiol. J., 21: 69-78.

Mirimanoff, N., Wilkinson, J. 2000. Regulation of $\mathrm{Zn}$ accumulation by a freshwater gram-positive bacterium (Rhodococcus opacus). Environ. Sci. Technol. 3:612-622.

Moran, M.A. \& Hodson, R.E. (1990) Bacterial production on humic and nonhumic components of dissolved organic carbon. Limnol. Oceanogr. 35:1744-1756.

Morel, F.M.M., Hering, J.G. 1983. Principle of Aquatic Chemistry, Weiley-Interscience, New York.

Mueller, K.K.; Lofts, S.; Fortin, C.; Campbell, P.G.C. 2012. Trace metal speciation predictions in natural aquatic systems: incorporation of dissolved organic matter (DOM) spectroscopic quality. Environ. Chem. 9:356-368.

Nogueira, P.F.M.; Melão, M.G.G.; Lombardi, A.T.; Vieira, A.H. 2005. The effects of Anabaena spiroides (Cyanophyceae) exopolisaccharide on copper toxicity to Simocephalus serrulatus (Cladocera, Daphinidae). Freshwater Biol. 50:1560-1567.

Nogueira, P.F.M.; Melão, M.G.G.; Lombardi, A.T.; Nogueira, M.M.; Vieira, A.H. 2009. The effects of Anabaena spiroids exopolysaccharides on copper accumulation in an aquatic food chain. Aquatic toxicol 93:125-130.

Nogueira, P.F.; Lombardi, A.T.; Nogueira, M.M. 2012. Cylindrospermopsis raciborskii exud a te Cu complexes: impact on copper dynamics and bioavailability in an aquatic food chain. Environ. Sci. Pollut. Res. Int. 19:1245-51.

Porter, K.G. \& Feig, Y.S. (1980) The use of DAPI for identifying and counting aquatic microflora. Limnol. Oceanogr. 25, 943-948. 
Reuter, J.H. \& Perdue, E.M. (1977) Importance of heavy metal-organic interactions in natural waters. Geochem. Cosmochem. Acta 41:325-334.

Romera-Castillo, C.; Sarmento, H.; Alvarez-Salgado, X.A.; Gasol, J.M.; Marrase, C. 2011. Net production and consumption of fluorescent colored dissolved organic matter by natural bacterial assemblages growing on marine phytoplankton exudates. Appl. Environ. Microbiol. 7490-7498.

Shim, H. \& Harris, Z.L. 2003. Genetic defects in copper metabolism. J. Nutrition 133: 1531-31537.

Sigg, L. \& Behra, R. 2005. Speciation and bioavailability of trace metals in freshwater environments. In: Sigel, A.; Sigel, H.; Sigel, R.K.O. (Eds) Metals ions in biological systems. Taylor and Francis group, Boca Rotan. pp. 47-73.

Silver, S. \& Le Phung, T. 2005. A bacterial view of the periodic table: genes and proteins for toxic inorganic ions. J. Ind. Microbiol. Biotechnol. 32:587-605.

Smiejan, A.; Wilkinson, K.O.; Rosser, C. 2003. Cadmium bioaccumulation by a freshwater bacterium Rhodospifillum rubrum. Environ. Sci. Technol. 37:701-706.

Tranvik, L.J. \& Sieburth, J. 1989. Effects of flocculated humic matter on free and attached pelagic microorganisms. Limnol. Oceanogr. 34:688-699.

Trenfield, M.A.; Ng, J.C.; Noller, B.N.; Markich, S.J.; Dam, R.A. 2011. Dissolved organic carbon reduces uranium bioavailability and toxicity. 2. Uranium [VI] speciation and toxicity to three tropical freshwater organisms. Environ. Sci. Technol. 45:3082-3089.

van Leeuwen, H.P.; Town, R.; Buffle, J.; Cleven, R.M.J.; Davison, W.; Puy, J.; van Riemsdijk, W.H.; Sigg, L. 2005. Dynamic Speciation Analysis and Bioavailability of Metals in aquatic systems. Environ. Sci. Technol. 39:22-29.

Wang, X.; Chen, X.; Liu, S.; Ge, X. 2010. Effect of molecular weight of dissolved organic matter on toxicity and bioavailability of copper to lettuce. J. Environ. Sci. 22:1960-1965.

Worms, I.; Simon, D.F.; Hassler, C.S.; Wilkinson, K.J. 2006. Bioavailability of trace metals to aquatic microorganisms: importance of chemical, biological and physical processes on biouptake. Biochimie 88:1721-1731.

Submetido: Janeiro/2014

Revisado: Junho/2014

Aceito: Abril/2015 